indirectly from observations of nuclear size and structure and directly from rare spontaneous mitoses in untreated roots, and in the treated roots (1) from the absence of nuclear abnormalities which might explain otherwise the origin of polyploid cells, (2) from the uniform occurrence of certain chromosome numbers in specific root tissues, (3) from proportions of diploid and polyploid divisions during mitotic induction, and (4) from the lack of relationship between total mitotic activity and number of poly. ploid mitoses. A gradient of endomitotic polyploidization exists in certain tissues along the longitudinal axis of the onion root.

\section{Rubber Diseases in the Belgian Congo}

R. J. PiCHEL (with the collaboration of C. Maertens) has produced a monographic study of rubber diseases and their control in the Congo basin (l'Inst. Nat. pour l'Etude Agr. du Congo Belge, Sér. Tech. No. 49 ; pp. $1-450,1956 ; 400 \mathrm{fr}$.). The first part of the book deals with the general problem of disease in rubber and the causative agents, the root-attacking fungi Fomes lignosus (Rigidoporus microporus) and Armil. laria mellea being of outstanding importance, as they also are in other rubber-growing regions. The attitude of the author to his subject is practical rather than detailed and specialized. 'The second part is devoted to observations on the biology of root-destroying fungi and the behaviour of Hevea under attack. The problem of infection courts is given special attention, and the processes and factors involved in contamination, infection and effective parasitism are considered at some length. In the third section, the epidemiology of the diseases and the efficacy of control measures are described with special reference to the considerable volume of work carried out at Yangambi, the effects of both direct methods and cultural treatments in controlling the pathogens being considered. The fourth section is concerned with control measures and the economic aspects of the problem. The conclusions and recommendations at the end represent a synthesis of the experience and the effort made in this field by the Belgian Congo workers at the Yangambi Research Station during recent years. The work is illustrated by a large number of excellent photographs, coloured plates and diagrams. This monograph contains a great deal of new observation of interest and importance to both pathologist and planter. A bibliography of more than three hundred titles is included.

\section{Breeding of Shags on Lundy Island}

DURING 1954 and 1955 observations were made on the breeding habits of shags on Lundy Island, and these have been described in the ninth annual report of the Lundy Field Society. Sufficient material was collected for some factors to emerge which appeai' to affect breeding success. The two years showed practically no difference in the pattern of clutch size although the weather was dissimilar. In both years there was a great predominance of clutches of three; there is a tendency for clutches laid later in the breeding season to be of a size greater, or less, than three. 'There was a striking similarity of hatching and fledging success in the two years, $93 \cdot 6$ per cent of young hatched during the two years reaching the flying stage--a remarkably high percentage. Even so, the number of young fledged was not sufficient to secure replacement of breeding adults. From the evidence of recoveries the yearling mortality is fairly high, and the species appears not to breed until at least three years old. Adults must average several seasons of breeding in order to replace themselves. All nests found have been divided into those situated under rocks and those open to the sky or with only slight rock overhang; covered nests are significantly more successful than open nests. Young in covered nests have shelter from rough weather and seas, and are not liable to be inadvertently pushed out of the nest and possibly over the cliff. Another significant factor in fledging success is the date of hatching. The earlier nests have a markedly higher rate of success than the late nests. It will be interesting to compare these results with those obtained by E. White and J. C. Coulson, who are studying shag mortality on the Farne Islands.

\section{Zoological Nomenclature}

As from December 12, 1956, the International Commission on Zoological Nomenclature will start to vote on the following cases involving the possible use of its plenary powers for the purposes specified against each entry. Full details have already been published (Bull. Zool. Nom., 12, Pts. 1 and 2 ; June 1956). (1) Paradoxides Brongniart, 1822, validation ; Olenus Dalman, [1827], designation of type species for ; paradoxus Linnaeus, 1759 (Entomolithus), suppression and Paradoxiden Emmrich, 1844 (wrongly based on Olenus) suppression (Cl. Trilobita); (2) munda Kuhl, 1820 (Proc.[ellaria] and Nectris), suppression (Cl. Aves); (3) Daira de Haan, [1833], validation (Cl. Crustacea, Order Decapoda); (4) tuberculatus Hall, 1859 (Acidaspis), validation; Acanthaloma Conrad, 1840, suppression (Cl. Trilobita) ; (5) Theridion Walckenaer, 1805 (Cl. Arachnida), designation of type species for ; (6) Protopeltura Brögger, 1822 (Cl. Trilobita), designation of type species for ; (7) punctata (Querquedula), validation of, as from Sclater (P.L.), 1880, as name for the hottentot teal (Cl. Aves); (8) Trinucleus Murchison, 1839, validation of ; tuberculatus Link, 1807 (Trinucleus), suppression (Cl. Trilobita); (9) Panulirus White, 1847, validation; commune Leach, 1818 (Phyllosoma) and rissonii Desmarest (Palinurus), suppression (Cl. Crustacea, Order Decapoda) ; (10) Illaenus Dalman, [1827], protection of by suppression of Cryptonymus Eichwald, 1825 (Cl. Trilobita). Comments should be sent as soon as possible to the secretary to the Commission, Mr. Francis Hemming, 28 Park Village East, Regent's Park, London, N.W.1.

\section{Ordnance Survey Map of Roman Britain}

Britarn was under Roman rule for nearly four hundred years, and, though subsequent influences from beyond the North Sea and from Normandy profoundly affected its people and their way of life, yet in many things the Roman pattern remained an ideal. A detailed survey of the various categories of Roman remains is therefore of great interest, and the new, third edition of the "Ordnance Survey Map of Roman Britain" is very welcome (pp. $43+1$ map ; paper flat, $3 s .3 d$.; folded, with text, $7 s .6 d$.; text only, $3 s$.$) . Much has been discovered since the$ last edition appeared about a quarter of a century ago, and methods of investigation have vastly improved. In every way the present publication is a great advance on the last, and Mr. C. W. Phillips, archæological officer for the Survey, is to be con. gratulated. It is a pity, perhaps, that such a large map had to be printed on such thin paper. It will not stand much use away from the study table, 